\title{
Production of recombinant protein G through high-density fermentation of engineered bacteria as well as purification
}

\author{
HU-CHENG ZHANG, JUN YANG, GUO-WEI YANG, XIAO-JIE WANG and HAI-TAO FAN \\ Department of Biology Engineering, Beijing Polytechnics, Beijing 100029, P.R. China
}

Received May 27, 2014; Accepted February 11, 2015

DOI: $10.3892 / \mathrm{mmr} .2015 .3688$

\begin{abstract}
Recombinant Streptococcus Protein G (PG) is a cell wall protein, which, when combined with mammal immunoglobulin, is used in separating antibody technology. High-density fermentation technologies using an engineered recombinant PG-producing bacteria as well as PG separation and purification technologies have a direct impact on the availability and application of PG. Through primary and secondary seed cultivation, a recombinant $E$. coli strain was subjected to high-density fermentation with controlled feed supplement concentration under stimulation with isopropyl $\beta$-D-1-thiogalactopyranoside. The present study investigated the effect of factors including inoculum size, oxygen levels, $\mathrm{pH}$ and the cultivating method on the fermentation process, as well as the effect of the separation and purification technologies, including ultrasonication, nickel column affinity chromatography, Sephadex G-25 gel filtration chromatography and diethylaminoethanol-sepharose fast flow ion exchange chromatography on the yield and purity of PG. The efficiency of extraction was detected using SDS-PAGE. High-density fermentation yielded $80-150 \mathrm{~g} / \mathrm{l}$ of bacteria and $1 \mathrm{~g}$ PG was obtained from one liter broth. The present study delivered a highly efficient novel method via which PG can be obtained at a high concentration and a purity $>95 \%$.
\end{abstract}

\section{Introduction}

Protein A separated from the Staphylococcus aureus cell wall (PA) can specifically combine with immunoglobulin (Ig)G, IgM and IgA in most mammals (1). Protein A can combine with the Fc fragment of immunoglobulin. The ligation of protein A with certain genes was shown not to influence binding sites between antibody and antigen (2). PA does not contain disulfide bonds due to absence of cysteine and cystine; its physical properties are therefore very steady (3).

Correspondence to: Dr Hu-Cheng Zhang, Department of Biology Engineering, Beijing Polytechnics, 1 Shaouaoju, Beijing 100029, P.R. China

E-mail: zhanghchbj@163.com

Key words: high-density fermentation, separation, purification, recombinant protein $\mathrm{G}$
Under acidic conditions, even combined with heating, the activity of PA does not change. PA exogenous expression was implemented in E. coli (4). Separated or recombinant PA specifically combines with Fc fragments of human IgG1, IgG2 and IgG4 in vitro. Since its discovery, PA has been received attention by various researchers and has a widespread application in immunology and molecular biology experiments (4).

Similar to protein A, protein $\mathrm{G}$ (PG) is an protein of the Streptococcus cell wall; however, it is more useful in $\mathrm{IgG}$ separation and purification (5). As protein A, protein $G$ can bind to the $\mathrm{Fc}$ region of immunoglobulin and numerous subtypes of $\mathrm{IgG}$, including $\mathrm{IgG} 1, \mathrm{IgG} 2, \mathrm{IgG} 3$ and $\mathrm{IgG} 4$ (6). Although the 4th spatial structure of protein $\mathrm{A}$ is similar to that of protein $\mathrm{G}$, they differ in their amino acid composition, and therefore, protein $\mathrm{G}$ but not protein A can be used for separating monoclonal antibodies (7). Compared with protein $\mathrm{A}$, protein $\mathrm{G}$ has a stronger IgG-binding capacity, but it does not bind to $\operatorname{IgM}, \operatorname{IgD}$ or $\operatorname{IgA}$. The affinity of protein $\mathrm{G}$ to Ig is more advanced than that of PA and of greater commercial value (3). During antibody separation and purification, albumin is the main contamination source; therefore, the albumin binding site on protein $\mathrm{G}$ was removed in preparation of the present study. For convenient purification, a $6 x \mathrm{His}$ label was added to the $\mathrm{C}$ terminal of protein $\mathrm{G}$ in our prelimary experiments, as described previously (8). E. coli high-density fermentation is widely applied in recombinant protein production and efficiency can be enhanced by improving parameters of these methods $(9,10)$. At present, there is only a limited number of studies on PG fermentation production as well as separation and purification. In the present study, PG was produced by high-density fermentation of recombinant gene engineered bacteria, and highly efficient separation and purification techniques were implemented, providing a theoretical and practical basis for further studies and PG production.

\section{Materials and methods}

Strain. The E. coli strain BL21 with recombinant vector pET32b-PG was established in our preliminary works (data not shown) at the Gene Engineering Laboratory of Bioengineering College of Beijing Electronic Technology Training College (Beijing, China) (8). The E. coli strains BL21 and pET32b were purchased from Takara Biotechnology., Co., Ltd. (Dalian, China). 
Ragents. Yeast extracts and tryptone were purchased from Oxoid Ltd. (Basingstoke, UK), and isopropyl $\beta$-D-1-thiogalactopyranoside (IPTG) and kanamycin were purchased from Takara Bio Inc. (Otsu, Japan). Buffers and solutions used were $1 \mathrm{~mol} / \mathrm{l} \mathrm{pH} 7.5 \mathrm{NaH}_{2} \mathrm{PO}_{4}-\mathrm{Na}_{2} \mathrm{HPO}_{4}$ buffer, $5 \mathrm{~mol} / \mathrm{l} \mathrm{pH} 7.5$ iminazole, $0.5 \mathrm{~mol} / 1 \mathrm{NaOH}, 0.1 \mathrm{~mol} / 1 \mathrm{NiSO}_{4}$, $4 \mathrm{~mol} / \mathrm{l} \mathrm{pH} 7.5 \mathrm{NaCl}$ and $20 \%$ ethanol solution. Unless otherwise stated, all other chemical reagents were purchased from Sinopharm Group Co., Ltd. (Beijing, China).

Instruments. The GE Image Scanner III (GE Healthcare, Little Chalfont, UK), a NBS5LBioflo3000 fermenter (New Brunswick Scientific Co., Edison, NJ, USA), an ultrasonicator (Ningbo Scientz Biotechnology Co., Ltd., Ningbo, China), a high-speed centrifuge (5810 R; Eppendorf, Hamburg, Germany), a Unico 7200 spectrophotometer (Unico Instrument Co., Shanghai, China), vertical slab electrophoresis apparatus (Bio-Rad Laboratories, Inc., Hercules, CA, USA), AKTA purifier UPC10 (GE Healthcare) and a chromatography column (diameter, $5 \mathrm{~cm}$; length, $20 \mathrm{~cm}$; Shanghai BioRc Co., Ltd., Shanghai, China) were used.

\section{Media}

Primary seed medium [Luria-Bertani (LB) medium]. The medium contained yeast extracts $(5 \mathrm{~g} / \mathrm{l})$, tryptone $(10 \mathrm{~g} / \mathrm{l})$ and $\mathrm{NaCl}(10 \mathrm{~g} / \mathrm{l})$ at $\mathrm{pH} 7.3$ in a total of 11 distilled water. The solution was sterilized at $121^{\circ} \mathrm{C}$ for $20 \mathrm{~min}$, and ampicillin $(50 \mu \mathrm{g} / \mathrm{m})$ and kanamycin $(50 \mathrm{mg} / \mathrm{l})$ were then added.

Secondary seed medium (2xYT medium). The medium contained yeast extracts $(10 \mathrm{~g} / \mathrm{l})$, tryptone $(16 \mathrm{~g} / \mathrm{l})$ and $\mathrm{NaCl}$ $(5 \mathrm{~g} / \mathrm{l})$ at $\mathrm{pH} 7.3$ in a total of 11 distilled water. The solution was sterilized at $121^{\circ} \mathrm{C}$ for $20 \mathrm{~min}$, and kanamycin $(50 \mathrm{mg} / \mathrm{l})$ and Amp $(50 \mu \mathrm{g} / \mathrm{ml})$ were added.

Fermentation medium. The medium contained yeast extracts (64 g), tryptone (102 g), glucose (6.4 g), disodium hydrogen phosphate (48 g), potassium dihydrogen phosphate (9.6 g), ammonium chloride (3.2 g), $\mathrm{CaCl}_{2}(0.035 \mathrm{~g}), \mathrm{NaCl}$ (1.6 g), $\mathrm{MgSO}_{4}(3.2 \mathrm{~g})$ and vitamin $\mathrm{B} 1(0.1 \mathrm{~g}), \mathrm{pH} 7.2$, with distilled water added to give 11 of total volume. The medium was sterilized under high pressure at $115^{\circ} \mathrm{C}$ for $30 \mathrm{~min}$, and Amp $(50 \mu \mathrm{g} / \mathrm{ml})$ and kanamycin $(50 \mathrm{mg} / \mathrm{l})$ were added.

Feed supplement medium. The medium contained yeast extracts (200 g), tryptone (20 g), glucose (10 g), $\mathrm{MgSO}_{4}(5 \mathrm{~g})$, $\left(\mathrm{NH}_{4}\right)_{2} \mathrm{SO}_{4}(5 \mathrm{~g})$ and vitamin $\mathrm{B} 1(0.1 \mathrm{~g})$, and distilled water was added to give $0.8-11$ of total volume. The medium was sterilized under high pressure at $115^{\circ} \mathrm{C}$ for $30 \mathrm{~min}$, and then Amp $(50 \mu \mathrm{g} / \mathrm{ml})$ and kanamycin $(50 \mathrm{mg} / \mathrm{l})$ were added.

Strain activation, cultivation and fermentation. Working seed medium preserved at $-20^{\circ} \mathrm{C}$ was defrosted. $10 \mu \mathrm{l}$ seed medium was diluted with a gradient from $10^{-5}$ to $10^{-6}$ to $10^{-7}$ and coated on an LB plate containing Amp and kanamycin for cultivating under $37^{\circ} \mathrm{C}$ for $16-18 \mathrm{~h}$ until single colonies were formed. For the primary seed $\mathrm{F}_{1}$ fermentation strain, a single colony was selected from the plate, inoculated in $50 \mathrm{ml} \mathrm{LB}$ medium containing Amp and kanamycin in a 250 -ml flask, cultivated at $37^{\circ} \mathrm{C}$ with agitation at $200 \mathrm{rpm}$ for $8-10 \mathrm{~h}$ until the optical density at $600 \mathrm{~nm}\left(\mathrm{OD}_{600}\right)$ of the bacterial suspension reached 0.025-0.035. For the second seed $\mathrm{F}_{2}$, the fermentation strain $\mathrm{F}_{1}$ was inoculated in $200 \mathrm{ml} 2 \mathrm{xYT}$ medium containing Amp and kanamycin in a 1,000-ml flask at $0.5 \%$ inoculum size, cultivated at $37^{\circ} \mathrm{C}$ with agitation at $200 \mathrm{rpm}$ for $7-8 \mathrm{~h}$ until the $\mathrm{OD}_{600}$ of the bacterial suspension reached 0.03-0.05.

$500 \mathrm{ml}$ grown $\mathrm{F}_{2}$ seed liquid was inoculated in a fermenter containing Amp and kanamycin and cultivated at $37^{\circ} \mathrm{C}$ until the $\mathrm{OD}_{600}$ reached 0.40-0.50. Subsequently, 0.1-0.2 mmol/1 IPTG was added for induction for 3.5-4.0 h. Compressed air was used as the air source with an air flow of $1 \mathrm{vvm}$ and $30-45 \%$ dissolved oxygen. Pure oxygen was added $2.5 \mathrm{~h}$ after initiation of fermentation, with the $\mathrm{pH}$ controlled at 7.0-7.2. Sampling was conducted once per hour to measure the $\mathrm{OD}_{600}$ until it reached a maximum value. The feed supplement speed was controlled using a feed supplement influx at $10-40 \%$ during the cultivating period, increased by $10 \%$ as the fermentation time progressed; it was controlled using a feed supplement influx at $20-40 \%$ during the induction period, with the maximum feed supplement speed in the first hour of the induction period. Feed supplementation was stopped half an hour prior to opening the fermenter at the end of the process.

Measurement of the concentration of recombinant engineered bacteria. A Unico 7200 spectrophotometer was adopted to measure the $\mathrm{OD}_{600}$, with distilled water as the control. The sample from fermentation broth was washed using distilled water three times, and diluted to $0.2-0.8$ at $\mathrm{OD}_{600}$.

Ultrasonic fragmentation of recombinant E. coli BL21. The centrifuged bacterial bodies were weighed and added into $10 \mathrm{mmol} / \mathrm{l}$ phosphate buffer $\left(\mathrm{pH} 7.0, \mathrm{Na}_{2} \mathrm{HPO}_{4}-\mathrm{NaH}_{2} \mathrm{PO}_{4}\right)$ at a ratio of 1:10. Following mixing, the suspension was cooled with ice water and subjected to ultrasonication at 200 watt for 100-150 times (10 sec on, $10 \mathrm{sec}$ off). Following ultrasonication, the solution was transferred into centrifuge tubes, centrifuged at $15,000 \mathrm{xg}$ for $>20 \mathrm{~min}$ with the supernatant carefully removed, and the supernatant was filtered through double layered filter paper and a $0.8-\mu \mathrm{m}$ membrane in sequence to remove any particles. To the filtered sample, $\mathrm{NaCl}(0.5 \mathrm{~mol} / \mathrm{l})$ and iminazole $(5 \mathrm{mmol} / \mathrm{l})$ were added, and the resulting solution was loaded onto columns for purification.

Nickel column purification. Five milliliter desalting solution (containing $1.46 \mathrm{mg}$ total protein) was purified on $30 \mathrm{ml}$ diethylaminoethanol-sepharose fast flow (DEAE-FF). Balance solution 1 (10 mmol/l sodium phosphate and $0.5 \mathrm{~mol} / \mathrm{l}$ $\mathrm{NaCl}$; pH 7.5) was used for balancing five column volumes at a flow speed of $1 \mathrm{~cm} / \mathrm{min}$; the sample was slowly pumped into the nickel nitrilotriacetic acid (Ni-NTA)-agarose column (Puribest, Shanghai, China) at a flow speed of $0.5 \mathrm{~cm} / \mathrm{min}$; following loading of the sample, the column was flushed with five column volumes of balance solution 1 and balance solution $2(10 \mathrm{mmol} / \mathrm{l}$ sodium phosphate and $0.05 \mathrm{~mol} / \mathrm{l} \mathrm{NaCl}$; $\mathrm{pH} 7.5)$ in sequence, followed by five column volumes of washing solution $1(10 \mathrm{mmol} / \mathrm{l}$ sodium phosphate, $0.05 \mathrm{~mol} / \mathrm{l}$ $\mathrm{NaCl}$ and $0.02 \mathrm{~mol} / \mathrm{l}$ iminazole; $\mathrm{pH}$ 7.5). The column was then flushed with 2-3 column volumes of spent eluent $1(10 \mathrm{mmol} / \mathrm{l}$ sodium phosphate, $0.05 \mathrm{~mol} / 1 \mathrm{NaCl}$ and $0.1 \mathrm{~mol} / 1$ iminazole; $\mathrm{pH}$ 7.5) for collecting the target protein, and then washed with regeneration solution 1 (10 mmol/l sodium phosphate, $0.05 \mathrm{~mol} / 1 \mathrm{NaCl}$ and $0.4 \mathrm{~mol} / 1$ iminazole; $\mathrm{pH} 7.5$ ) for regeneration of the nickel column. 
Gel filtration (Sephadex G-25) for desalination. The column was washed with five column volumes of balance solution 3 (10 mM sodium phosphate; $\mathrm{pH} 7.5)$ at a flow speed of $1 \mathrm{~cm} / \mathrm{min}$. The sample was then loaded onto the column, and at a flow speed of $0.5 \mathrm{~cm} / \mathrm{min}$, the column was flushed with five volumes of balance solution 3 for collecting the protein sample.

Negative ion exchange column purification DEAE-FF. Five milliliter lysate was purified on $20 \mathrm{ml} \mathrm{Ni-NTA}$ Agarose, using a UV280 $\mathrm{nm}$ detector to detect the products. Five column volumes of balance solution $3(10 \mathrm{mM}$ sodium phosphate solution; $\mathrm{pH}$ 7.5) were used for balancing at a flow speed of $1 \mathrm{~cm} / \mathrm{min}$. The sample was slowly loaded onto the column (Puribest), and at a flow speed of $0.5 \mathrm{~cm} / \mathrm{min}$, the column was flushed with five column volumes of balance solution 3 and washing solution $2(10 \mathrm{mmol} / 1$ sodium phosphate and $0.05 \mathrm{~mol} / 1 \mathrm{NaCl} ; \mathrm{pH} 7.5)$ in sequence. Subsequently, the column was washed with 2-3 column volumes of spent regenerant $2(10 \mathrm{mmol} / \mathrm{l}$ sodium phosphate and $0.1 \mathrm{~mol} / 1 \mathrm{NaCl}$; $\mathrm{pH} 7.5)$, spent regenerant $3(10 \mathrm{mmol} / \mathrm{l}$ sodium phosphate and $0.15 \mathrm{~mol} / \mathrm{l} \mathrm{NaCl} ; \mathrm{pH} 7.5)$ and spent regenerant $4(10 \mathrm{mmol} / \mathrm{l}$ sodium phosphate and $0.2 \mathrm{~mol} / \mathrm{l} \mathrm{NaCl} ; \mathrm{pH} 7.5$ ) for eluting the target protein. The column was then treated with regeneration solution $2(10 \mathrm{mmol} / 1$ sodium phosphate and $0.5 \mathrm{~mol} / 1 \mathrm{NaCl}$; $\mathrm{pH}$ 7.5) for regenerating the ion exchange solid phase.

Protein detection. The recombinant PG (rPG) protein in the samples was identified as follows: $12 \%$ SDS-PAGE (Bio-Rad Laboratories, Inc.), gel staining with $0.25 \%$ Commassie Blue staining solution (methanol: acetic acid: $\left.\mathrm{dH}_{2} \mathrm{O}=5: 1: 5\right)$, destaining with a solution (methanol: acetic acid: $\left.\mathrm{dH}_{2} \mathrm{O}=2: 3: 35\right)$. Following destaining, the gel was visualized by GE Image scanner III (GE Healthcare). The protein concentration was measured by the methods according to Bradford or Lowry (11) with bovine serum albumin as the standard (8).

Purity determination and identification of $r P G$. The purified dried $\mathrm{rPG}$ was dissolved in $50 \mathrm{mM}$ sodium phosphate buffer (pH 7.2) containing $50 \mathrm{mM} \mathrm{NaCl}$ and underwent high performance liquid chromatography (HPLC; Agilent 1200, Santa Clara, CA, USA; TSK-GEL G2000SWXL, $5 \mu \mathrm{m}, 7.8 \mathrm{~mm} \times 300 \mathrm{~mm}$; Tosoh Co., Tokyo, Japan), alongside molecular weight standards bovine serum albumin $(66.4 \mathrm{kDa})$, ovalbumin $(44.3 \mathrm{kDa})$, pepsin $(35.0 \mathrm{kDa})$, lysozyme (14.3 kDa), insulin (58.8 kDa) and hydroxocobalamine $(1.4 \mathrm{kDa})$. All the standards were purchased from Tiangen (Tiangen Biotech Co., Ltd, Beijing, China). The mobile phase, at a flow rate of $0.5 \mathrm{ml} / \mathrm{min}$, was $50 \mathrm{mM}$ sodium phosphate buffer ( $\mathrm{pH}$ 7.2) containing $50 \mathrm{mM} \mathrm{NaCl}$. The experiment was monitored using a UV detector $(280 \mathrm{~nm})$.

The purified rPG and the commercialized PG were separated by $12 \%$ SDS-PAGE gel, and were transferred to polyvinylidene difluoride (PVDF) membranes using semi-dry electro-blotting apparatus (Bio-Rad Laboratories, Inc.). The transfer was carried out for $2 \mathrm{~h}$ at $18 \mathrm{~V}$. Subsequently, the membranes were blocked with TBST $(20 \mathrm{mmol} / \mathrm{l}$ Tris- $\mathrm{HCl}$, $\mathrm{pH} 8.0 ; 150 \mathrm{mmol} / 1 \mathrm{NaCl} ; 0.05 \%$ Tween) containing 5\% non-fat milk for $1 \mathrm{~h}$, and then incubated with a 1:10,000 dilu- tion of goat horseradish peroxidase-conjugated anti-Protein $\mathrm{G}$ antibody (cat. no. SA101; Tiangen Biotech Co., Ltd) at room temperature for $1 \mathrm{~h}$. The membrane was then washed six times with TBST (10 min per wash), and positive bands in the membrane were detected by Enhanced Chemiluminescent reagent (Beyotime Institute of Biotechnology, Beijing, China).

Statistical analysis. SPSS 13.0 statistical software (SPSS Inc., Chicago, IL, USA) was used to analyze the data. Measurement data were compared using one-sample t-test. $\mathrm{P}<0.05$ was considered to indicate a statistically significant difference.

\section{Results}

Influence of the seed inoculum size on the productivity and time of fermentation. The productivity and time of PG fermentation were influenced by the inoculum size in the fermenter. In the fermentation experiments, inoculum sizes of 5, 10 and $15 \%$ were adopted (Fig. 1) in order to observe their influence on the mass of bacterial bodies. The results indicated that at a relatively low inoculum size of 5\%, the lag phase was significantly longer, which may be due to strain aging, extended growth time and a lower number of bacteria in the stationary phase, resulting in lower protein expression. However, at 10\% inoculum size, the lag phase was significantly shortened, and the rapid proliferation of recombinant bacteria during fermentation made them enter the Logarithmic growth phase earlier with more nutrition for target product synthesis, leading to a recombinant PG productivity of $20 \mathrm{mg} / \mathrm{l}$ (Fig. 2). When the inoculum size was $15 \%$, the large amount of bacteria exhausted the availability of nutrition bacterial growth, resulting in a very short lag phase. The density of bacteria in the stationary phase was $>10 \%$ of the inoculum size, but exogenous PG productivity decreased (Fig. 2); the potential cause of this is that nutrition was absorbed by the large amount of bacteria, while there was less nutrition for PG production; in addition, the metabolic waste of the bacteria may have had a negative effect on subsequent PG synthesis.

Dissolved oxygen levels affect the productivity and time of fermentation. The dissolved oxygen concentration is another important factor influencing bacterial growth during high-density fermentation. The bacterial density and recombinant protein productivity are influenced by the concentration of dissolved oxygen. E. coli require a large amount of oxygen for metabolism during rapid proliferation, and therefore, a timely supply of saturated oxygen is very important. The bacterial density was very high at the late period of high-density fermentation, which therefore required extremely large amounts of dissolved oxygen to maintain target protein synthesis. The compressed air used in the present study was not sufficient to meet the oxygen demand of the bacteria, as indicated by a $\mathrm{DO}_{2}$ value of 0 or even a negative value, high bacterial density and a bacterial wet weight of $150 \mathrm{~g} / \mathrm{l}$, while PG expression levels remained low. During the initial fermentation period, the required quantities of oxygen were not high; therefore, the present study used pressured air with levels of dissolved oxygen controlled at $30-45 \%$ during the initial period. Following $2.5 \mathrm{~h}$ of fermentation, oxygen was added, 
Table I. Summary of the purification of rPG expressed in E. coli BL21.

\begin{tabular}{lccccc}
\hline Purification step & Volume $(\mathrm{ml})$ & Total protein $(\mathrm{mg})$ & rPG $(\mathrm{mg})$ & Purity $(\%)$ & Cumulative yield $(\%)$ \\
\hline Ultra sonication & $10 \pm 1$ & $29.2 \pm 0.3$ & $7.8 \pm 0.5$ & $26.7 \pm 2$ & 100 \\
Ni-NTA chromatography & $20 \pm 1.5$ & $7.5 \pm 0.2$ & $7.2 \pm 0.1$ & $96.1 \pm 3.9$ & $92.8 \pm 7.3$ \\
Desalting column & $25 \pm 2.3$ & $7.3 \pm 0.1$ & $7.0 \pm 0.1$ & $95.9 \pm 2.7$ & $90.2 \pm 7.1$ \\
DEAE-FF & $15 \pm 1.8$ & $6.9 \pm 0.1$ & $6.7 \pm 0.1$ & $97.1 \pm 2.8$ & $86.3 \pm 6.8$ \\
\hline
\end{tabular}

rPG, recombinant Staphylococcus protein G; Ni-NTA, nickel nitrilotriacetic acid-agarose column; DEAE-FF, diethylaminoethanol-sepharose fast flow.

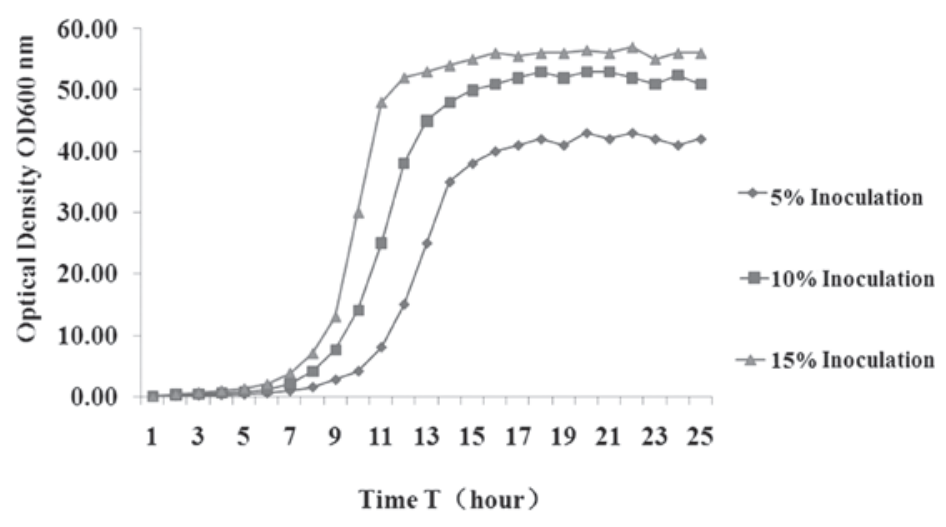

Figure 1. Effect of inoculum size on E. coli content.

and at the late period of fermentation, high-pressure pure oxygen was supplied to enhance the oxygen supply.

Influence of the $\mathrm{pH}$ on fermentation efficiency. $\mathrm{pH}$ variance in the fermentation environment influences the internal environment and variance in the cell metabolism of bacteria; furthermore, it directly influences the biomass of genetically engineered bacteria and the amount of gene expression of the product. The influence of the initial $\mathrm{pH}$ value of the medium on the production of $\mathrm{PG}$ was investigated in the present study. A higher or lower initial $\mathrm{pH}$ value of the medium resulted in reduced $\mathrm{PG}$ expression, while maximum production of recombinant $\mathrm{PG}$ was achieved when the $\mathrm{pH}$ of the medium was 7.0 at the beginning of the fermentation (Fig. 3).

IPTG influences the amount of PG expression. Following the logarithmic phase, the bacteria were cultivated with the inducer IPTG at $0,0.1,0.2,0.3,0.4$ and $0.5 \mathrm{mmol} / 1$ for $4 \mathrm{~h}$, and the content of recombinant PG in the soluble protein of the bacteria was analyzed. The amount of rPG expression increased as the IPTG concentration was enhanced, but above a concentration of $0.2 \mathrm{mmol} / 1 \mathrm{IPTG}$ did not lead to any further obvious improvement of PG expression; in fact, it decreased to a certain extent (results not shown). Therefore, the IPTG concentration used for induction was fixed at $0.2 \mathrm{mmol} / \mathrm{l}$. The induction time of IPTG influenced the levels of PG expression, as shown in Fig. 4. The amount of rPG protein expression gradually increased as the induction time was increased from $1 \mathrm{~h}$ and reached a peak when induction was performed for $4 \mathrm{~h}$, leading to an $\mathrm{rPG}$ yield of $20 \%$ of total proteins. However, further extension of the induction time decreased the yield of

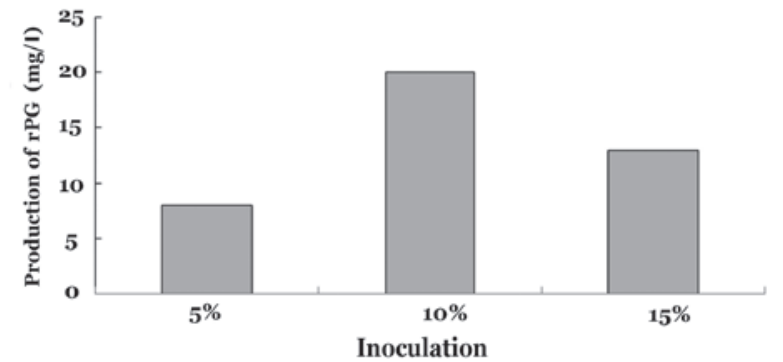

Figure 2. Effect of inoculation on $\mathrm{rPG}$ production. $\mathrm{rPG}$, recombinant Staphylococcus protein G.

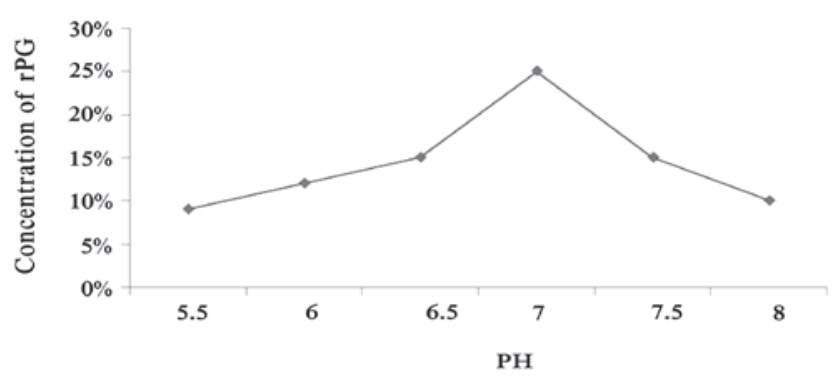

Figure 3. Effect of $\mathrm{pH}$ on $\mathrm{rPG}$ concentration. Percentage of $\mathrm{rPG}$ refers to the toal protein expressed in the cell. rPG, recombinant Staphylococcus protein G.

recombinant $\mathrm{PG}$, which may be due to degradation or denaturation of PG over longer time periods. 


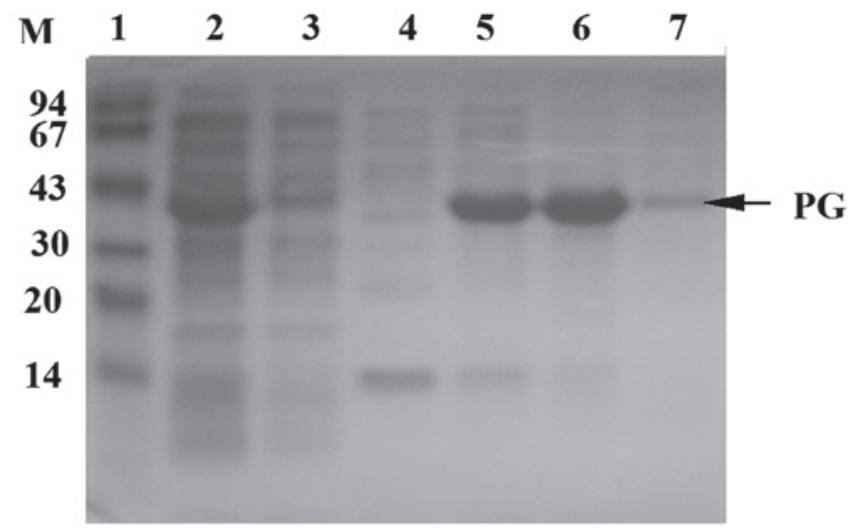

Figure 4. Influence of induction time and purification techniques using Ni-NTA or DEAE-FF chromatography on the yield and purity of rPG. Lanes: 1, Protein molecular weight marker; lanes 2-4, crude lysates of engineered bacterial strain pET32a-PG following induction by isopropyl $\beta$-D-1-thiogalactopyranoside for 4, 5 and 6 h, respectively; lane 5, eluate from Ni-NTA column; lane 6, eluate from DEAE-FF column. rPG, recombinant Staphylococcus protein G; Ni-NTA, nickel nitrilotriacetic acid-agarose; DEAE-FF, diethylaminoethanol-sepharose fast flow.

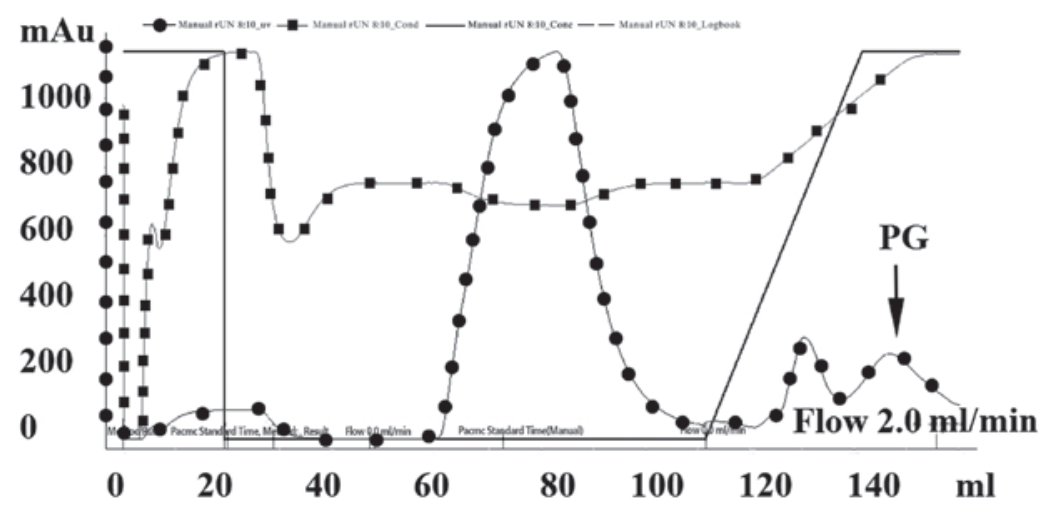

Figure 5. Chromatogram for the purification of rPG using a nickel nitrilotriacetic acid-agarose column. PG, recombinant Staphylococcus protein G.

A

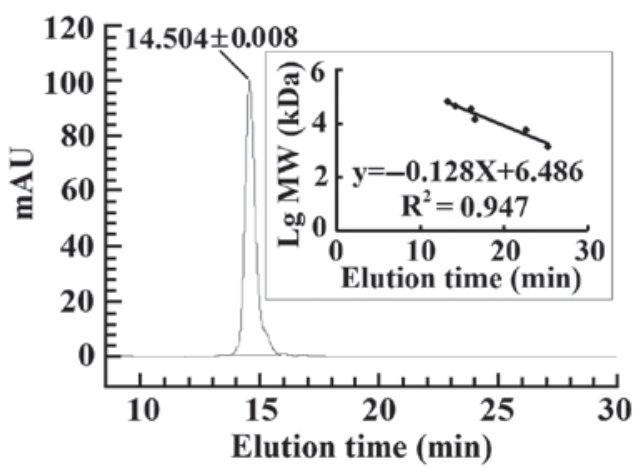

B

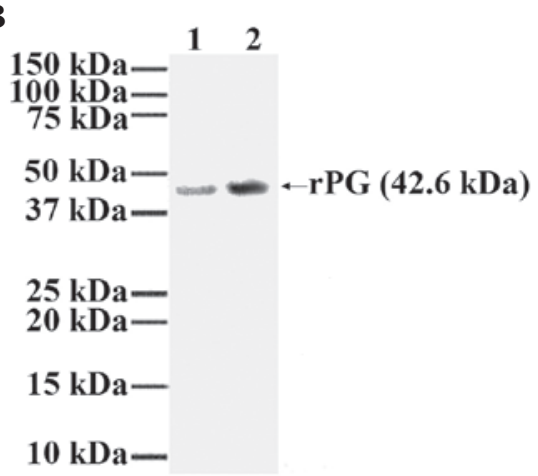

Figure 6. Purity (A) determination and (B) identification of rPG. (A) Gel filtration elution profile of rPG showed the molecular weight of rPG to be $42.6 \mathrm{kDa}$ with $100 \%$ purity. (B) Western blot analysis was conducted to compare the purified rPG with the commercialized PG. Lane 1, commercialized PG binding to goat IgG; Lane 2, purified rPG binding to goat IgG. rPG, recombinant Staphylococcus protein G; IgG, immunoglobulin G.

$P G$ separation and purification. Metal chelate affinity chromatography, also known as fixed metal ion affinity chromatography, utilizes the coordination interaction between various metal ions, including $\mathrm{Cu}^{2+}, \mathrm{Zn}^{2+}, \mathrm{Ni}^{2+}, \mathrm{Co}^{2+}$ and $\mathrm{Fe}^{3+}$, and histidines on the protein surface as a principle for separation and purification. Agarose gel containing these fixed metal ions is able to selectively purify proteins containing multiple histidines. In a previous study (12), PG with a
C terminus containing six histidines was separated from cell lysate using a Ni-NTA affinity column, desalinated by gel filtration (Sephadex G-25) and purified by anion exchange column (DEAE-FF). In the present study, PG was obtained at a maximum yield following one step of nickel column affinity chromatography (Fig. 5). Following gel filtration and anion exchange column chromatography, an PG purity of $>95 \%$ was achieved (Fig. 4). 
Purity and identification of $r P G$. The purified $\mathrm{rPG}$ showed a single peak at UV adsorption $280 \mathrm{~nm}$ following HPLC (Fig. 6A). To detect the IgG-binding ability of the purified rPG and compare the ability with that of the commercialized PG, each protein was separately immobilized onto PVDF at a protein concentration of $15 \mu \mathrm{g}$ for the purified $\mathrm{rPG}$ and the commercialized PG. The purified rPG and the commercialized PG were shown to bind well to goat IgG (Fig. 6B).

Statistical analysis of purification methods. The highest rPG expression level was $>20 \%$ of the total protein being expressed. The rPG was isolated and purified with affinity Ni-NTA chromatography and Anion exchange DEAE-FF chromatography. A final yield of $15 \pm 1.8 \mathrm{ml}$ of $0.45 \mathrm{mg} / \mathrm{ml} \mathrm{rPG}$ was obtained, giving a cumulative yield of $86.3 \pm 6.8 \%$ for $\mathrm{rPG}$ (Table 1).

\section{Discussion}

PG is a cell wall protein separated from Streptococcus and is able to bind to the Fc fragment of IgG of most mammals, but it binds to human $\operatorname{IgM}$, IgD and $\operatorname{Ig} \mathrm{A}$. In preliminary experiments, a recombinant $E$. coli strain expressing PG was generated, with albumin and cell surface binding sites removed in order to reduce cross reaction and non-specific binding. Therefore, recombinant $\mathrm{PG}$ had higher affinity for Igs than natural protein $\mathrm{G}$ and protein $\mathrm{A}$; it can be applied widely in immunochemistry by replacing secondary antibodies whilst having high affinity and stability. PG high density fermentation technology using the recombinant $E$. coli BL21 strain as well as improved conditions of recombinant $\mathrm{PG}$ separation and purification were assessed in the present study in order to establish a basis for the development of a large-scale production of PG.

In high-affinity fermentation, the biggest difficulty is the large amount of acetic acid generated during the fermentation process, which has an inhibiting effect on bacterial growth and protein expression (13). Acetic acid synthesis is influenced by the strain type, cultivating conditions and carbon source supply method. To eliminate acetic acid during high-density fermentation, genes associated with acetic acid synthesis are removed by gene engineering method and acetic acid is removed by dialysis (13). Simply increasing the biomass does not always increase the productivity but likely results in acetic acid accumulation (14). During fermentation in the present study, acetic acid synthesis was reduced by balancing the feed supplements, which is the most common method (15-17). In the present study, nutrition such as a carbon source was added at the exponential growth phase in order to ensure that nutrition and oxygen supply are maximal, according to the methodology used in most high-density fermentation processes (18). In the present study, the concentration of acetic acid was reduced using recombinant $E$. coli BL21 and a carbon source was added to balance the feed supplements.

High production of target proteins depends on high concentration of bacteria, which in turn largely depends on a saturated oxygen supply during high-density fermentation. The oxygen demand of the microorganisms largely exceeded the oxygen concentration supplied in the fermentation device. In the present study, the oxygen concentration was artificially enhanced by using pure oxygen (13) and enhancing the oxygen gas pressure $(17,19)$.
Apart from being influenced by acetic acid and oxygen, the production of PG target protein is influenced by nutrition. In the present study, high concentrations of bacteria and protein product were obtained by controlling the influx speed and concentration of feed supplement (20).

Ni-NTA affinity column chromatography allowed for simple recombinant protein separation, as it contained a 6xHis affinity label, providing it with adsorption sites. In perliminary experiments, a 6 His codon was added to the $\mathrm{C}$-terminal region of the PG gene to facilitate the extraction of large amounts of target protein from bacterial lysate. PG was obtained at high purity through desalination by gel filtration and ion exchange chromatography.

A subsequent study will focus on further exploration of recombinant $\mathrm{PG}$ activity.

\section{Acknowledgements}

The present study was funded by the Beijing Municipal Education Commission of Science and Technology General Program (no. SQKM201210858002).

\section{References}

1. Bjork I, Petersson BA and Sjoquist J: Some physiochemical properties of protein A from Staphylococcus aureus. Eur J Biochem 29: 579-584, 1972.

2. Chen YW, Wang H, Hupert M and Soper SA: Identification of methicillin-resistant Staphylococcus aureus using an integrated and molecular microfluidic system. Analyst 138: 1075-1083, 2013.

3. Sheerin DJ, Menon C, Zur Oven-Krockhaus S, Enderle B, Zhu L, Johnen P, Schleifenbaum F, Stierhof YD, Huq E and Hiltbrunner A: Light-activated phytochrome A and B interact with members of the SPA family to promote photomorphogenesis in Arabidopsis by reorganizing the COP1/SPA complex. Plant Cell 27: 189-201, 2015.

4. Graille M, Stura EA, Corper AL, Sutton BL, Taussig MJ, Charbonnier JB and Silverman GJ: Crystal structure of a Staphylococcus aureus protein A domain complexed with the Fab fragment of a human $\operatorname{IgM}$ antibody: structural basis for recognition of B-cell receptors and super antigen activity. Proc Natl Acad Sci USA 97: 5399-5404, 2000.

5. Ditse Z, Adrian PV, Kuwanda L and Madhi SA: Association of Streptococcus pneumoniae common protein antigen (CPA) antibodies and pneumococcal nasopharyngeal colonization in HIV-infected and HIV-uninfected African children. Vaccine 31: 4421-4427, 2013.

6. Kmiecik S and Kolinski A: Folding pathway of the B1 domain of protein $\mathrm{G}$ explored by a multiscale modeling. Biophys $\mathrm{J} 94$ : 726-736, 2008.

7. Eliasson M, Andersson R, Olsson A, Wigzell H and Uhlén M: Differential IgG-binding characteristics of staphylococcal protein $A$, streptococcal protein $G$, and a chimeric protein AG. J Immunol 142: 575-581, 1989.

8. Green MR and Sambrook J (eds): Expressing cloned genes for protein production, purification, and analysis. In: Molecular cloning. 4th edition. Cold Spring Harbor Laboratory Press, Long Island, NY, pp1481-1611, 2012.

9. Lee $\mathrm{Y}$ and Blanch $\mathrm{H}$ : Recombinant protein expression in high cell density fed-batch cultures of Escherichia coli. Biotech 10: 1550-1556, 1992.

10. Riesenberg D and Guthke R: High-cell-density cultivation of microorganisms. Appl Microbiol Biotechnol 51: 422-430, 1999.

11. Lowry OH, Rosenburg NJ, Farr AL and Randall RJ: Protein measurement with the Folin phenol reagent. J Biol Chem 193: 265-275, 1951.

12. Hutt M, Färber-Schwarz A, Unverdorben F, Richter F and Hontermann RE: Plasma half-life extension of small recombinant antibodies by fusion to immunoglobulin-binding domains. J Biol Chem 287: 4462-4469, 2012. 
13. Jenzsch M,Lange M, Bär J, Rahfeld JU and Lubbert A: Bioreactor retrofitting to avoid aeration with oxygen in Pichia pastoris cultivation processes for recombinant protein production. Chem Eng Res Design 82: 1144-1152, 2004.

14. DeLisa MP, Chae HJ, Weigand WA, Valdes JJ, Rao G and Bentley WE: Generic model control of induced protein expression in high cell density cultivation of Escherichia coli using on-line GFP-fusion monitoring. Bioproc Biosyst Eng 24: 83-91, 2001.

15. Lara AR, Caspeta L, Gosset G, Bolívar F and Ramírez OT: Utility of an Escherichia coli strain engineered in the substrate uptake system for improved culture performance at high glucose and cell concentrations: An alternative to fed-batch cultures. Biotechnol Bioeng 99: 893-901, 2008.

16. Matsui T, Sato H, Yamamuro H, Misawa S, Shinzato N, Matsuda H, Takahashi J and Sato S: High cell density cultivation of recombinant Escherichia coli for hirudin variant 1 production. J Biotechnol 134: 88-92, 2008.
17. Knoll A, Bartsch S, Husemann B,Engel P, Betina S, Stockmann C, Seletzky J and Buchs S: High cell density cultivation of recombinant yeasts and bacteria under non-pressurized and pressurized conditions in stirred tank bioreactors. J Biotechnol 132: 167-179, 2007.

18. Sandén AM, Prytz I, Tubulekas I, Förberg C, Le H, Hektor Andrea, Neubauer Peter, Pragai Z, Harwood C, Ward A, Picon A, de Mattos JT, Postma P, Farewell A, Nyström T, Reeh S, Pedersen S and Larsson G: Limiting factors in Escherichia coli fed-batch production of recombinant proteins. Biotechnol Bioeng 81: 158-166, 2003.

19. Belo I, Pinheiro R and Mota M: Fed-batch cultivation of Saccharomyces cerevisiae in a hyperbaric bioreactor. Biotechnol Prog 19: 665-671, 2003.

20. Eiteman MA and Altman E: Overcoming acetate in Escherichia coli recombinant protein fermentations. Trends Biotechnol 24: 530-536, 2006. 